\section{O conceito de}

\section{cidadania, origens \\ históricas e bases}

conceituais:

os vínculos com a

Comunicação

\section{RESUMO}

Quais os pressupostos, as premissas para a qualificação democrática para a sociedade moderna de massas? Apesar da questão ser complexa, existem procedimentos que oferecem condições mínimas para se enfrentar a questão. A dificuldade está situada no fato de sociedades poderem ser mais ou menos democrática que outras. Como democracia é movimento, é meio e fim ao mesmo tempo, procedimentos democráticos são necessários para que se assegurem as decisões públicas.

\section{ABSTRACT}

What are the premisses to qualify modern mass societies as being democratic ones? Despite the complexity of such a question, there are means which offer minimal conditions to resolve that problem. But the true difficulty lays in the fact that a society may be more or less democratic than others. Since democracy is movement, is a means and is an end at the same time, what we really need is more democratic procedures to guarantee public decisions,

\section{PALAVRAS-CHAVE}

- Comunicação (Comunication)

- Democracia (Democracy)

- Filosofia Polítca (Pollitical Philosophy)
Quais os pressupostos, as premissas para a qualificação de democrática para a sociedade moderna de massas? Apesar da questão ser complexa, existem procedimentos que oferecem condições mínimas para se enfrentar a questão. A dificuldade está situada no fato de sociedades poderem ser mais ou menos democráticas que outras. Como democracia é movimento, é meio e fim ao mesmo tempo, procedimentos democráticos são necessários para que se assegurem as decisões públicas.

O fundamental é entender que uma sociedade democrática pode democratizar-se mais. Em outras palavras: é possível democratizar ademocracia,tornarumasociedade democrática mais democrática ainda ${ }^{1}$. Inevitável reafirmar-se, aqui, que a idéia de uma democracia de massas pode ser entendida, também, como a idéia de uma democracia o mais democrática possível.

Neste sentido, parto da formulação de Norberto Bobbio, que define democracia com uma sociedade "caracterizada por um conjunto de regras (primárias ou fundamentais) que estabelecem quem está autorizado a tomar decisões coletivas e com que quais procedimentos (Bobbio, 1986). Assim, o direito ao voto, ou seja, à participação na escolha de quem vai exercer o poder, é um critério fundamental, no qual, o ideal limite é a "onicracia", o poder de todos.

Entretanto, reconhecendo este ideal limite como inalcançável, Bobbio chama a atenção para o fato de que o processo de democratizar a democracia é sempre passível de novos passos:

"Uma sociedade na qual os que têm direito ao voto são os cidadãos masculinos maiores de idade é mais democrática do que aquela na qual votam apenas os proprietários e é menos democrática do que aquela em que têm direito ao voto também as mulheres. Quando se diz que no século passado ocorreu em alguns países 
um contínuo processo de democratização quer-se dizer que o número dos indivíduos com direito ao voto sofreu um progressivo alargamento" (Bobbio, 1986, pg 19).

Esta concepção implica a observância de três regras básicas decorrentes de vínculos estabelecidos internamente numa sociedade para que seja possível tomar decisões e aceitálas coletivamente.

A primeira, que se refere à modalidade de decisão, tem como fundamental o critério de maioria. Em seguida encontra-se a definição de quais cidadãos devem participar, direta ou indiretamente das decisões coletivas.

A terceira regra defendida por Bobbio refere-se às condições de escolha e decisão dos cidadãos chamados a decidir ou eleger e que, para tanto, precisam ser garantidos os direitos de liberdade de opinião, de expressão, de reunião, de associação, etc. (Bobbio, 1986). A estas condições, Bobbio vincula o modelo de sociedade liberal democrática.

O mesmo fenômeno da pobreza², que emergiu paraa consciência moderna através dos debates de opinião referentes ao sindicalismo, ao socialismo, ao anarquismo, ao humanismo (Polanyi, 1980), forjou ao liberalismo utilitarista ao longo dos três últimos séculos uma consciência política que assegurou gradativamente um elenco de direitos humanos, finalmente formalizados na Declaração Universal dos Direitos Humanos, de 1948, da Organização das Nações Unidas.

Registre-se a observação de que esta tendência à universalização destes direitos, consagrados como "direitos humanos" e ostentados em declarações internacionais, vai fazendo - esta é uma tendência complexa, difícil de se concretizar e é de longo prazo, mas aparentemente irreversível - com que a noção de cidadania ultrapasse as fronteiras dos Estados nacionais e consagre a noção do homem como "cidadão do mundo"3. Além disso, o progresso tecnológico tem feito com que temas emergentes como, por exemplo, a engenharia genética e a ecologia imponham ao mundo a necessidade de formulação de novos direitos que vão sendo concebidos, nestas circunstâncias, já como "universais" e "mundiais".

Este conjunto de circunstâncias possibilitou à esfera pública burguesa um espaço de debates com a função política de transformar pessoas privadas em sujeitos da esfera pública.
Este processo aparece como um problema para a consciência moderna, com os grandes debates de opinião que originaram os sindicatos profissionais e os sistemas de idéias vinculadas ao socialismo.

Trata-se de um espaço de debates com a função política de transformar pessoas privadas em sujeitos da esfera pública (Habermas, 1984).

A generalização da propriedade privada, a separação do trabalho da terra e do capital, assim como a divisão do trabalho, o estabelecimento da livre concorrência e do lucro como legítimos, a produção e a acumulação do capital, alargaram as condições materiais para a organização da sociedade, que, em sua evolução, gradativamente separa as esferas da vida privada da pública, que se apresentavam até então como unidade inseparável (Habermas, 1984).

Como resultado emerge histórica e juridicamente o Estado liberal e democrático, interdependências de tal modo, que se consolida a idéia de que é o espaço da democracia liberal que eticamente irá concretizar capacidades humanas individuais, desenvolvendo forças produtivas competitivamente, isto é, nos pressupostos do mercado de mercadorias e idéias. (MacPherson, C. 1991)

As sociedades ocidentais que se desenvolvem a partir do século XVIII geraram um sistema político que exige dos cidadãos racionalidade e zelo para operar e controlar o sistema político. Esta condição foi dada estruturalmente pela esfera política a partir do desenvolvimento e da expansão dos direitos políticos que geraram grupos de opinião e condutas políticas fundadas nas mais diversas condições - conservadoras, tradicionalistas, liberais, reformadoras e revolucionárias.

Somente nas sociedades capitalistas forjadas a partir do século XVIII, que desenvolveram relações de reciprocidade entre as pessoas fundadas num modelo de homem e numa teoria eticamente justificável, tornou-se possível o desenvolvimento de necessidades e capacidades humanas e sociais (Macpherson, 1991). Tais foram as condições essenciais que permitiram a constituição das sociedades de massas democráticas capitalistas contemporâneas.

Este novo ordenamento social organizou e deu origem a uma nova sociedade que igualizou formalmente direitos, protegeu os "desiguais", assegurou liberdades civis em torno 
do princípio da liberdade individual compatível com igual liberdade dos outros (MacPherson, 1991), tornando possível a emergência de uma nova sociedade com um espaço social e político diferenciado, cujos mecanismos de funcionamento possibilitaram o aparecimento das divergências que complexificam as relações do cidadão com o espaço público.

No entender de Jürgen Habermas, público é um conceito que, ao se expandir, assume dois sentidos: um referente a relações, ações, cargos, instituições e prédios ligados ao governo, e outro às ações e manifestações produzidas pela imprensa para se obter publicidade e opinião pública. (Habermas, 1984. ) Com a emergência da sociedade burguesa e suas estruturas produtivas de idéias e mercadorias surge a genuína autonomia da esfera privada em contraposição ao público. O termo privado denominaria todos os atos, negócios, cargos, ou casa e indivíduos excluídos da autoridade pública.(Habermas, 1984).

Segundo Norberto Bobbio, no pensamento de Habermas,"entende-se que a maior ou menor relevância da opinião pública entendida como opinião relativa aos atos públicos, isto é, aos atos próprios do poder público que é por excelência o poder exercido pelos supremos órgãos decisórios do Estado, da 'res-pública', depende da maior ou menor oferta ao público, entendida esta exatamente como visibilidade, cognoscibilidade, acessibilidade e portanto controlabilidade dos atos de quem detém o supremo poder" (Bobbio, 1986).

No entanto, Bobbio considera discutível a obra de Habermas, "porque jamais são distinguidos, no curso de toda a análise histórica, os dois significados de 'público': quais sejam, 'público' como pertencente à esfera estatal, à 'res-pública', que é o significado originário do termo latino publicum, transmitido pela distinção clássica entre ius privatum e ius publicum, e 'público' como manifesto (que é o significado do termo alemão offentliches), oposto a secreto(Bobbio, 1986).

Benjamin Constant observava, com rigor, a distinção entre esfera pública e esfera privada e que era exatamente esta distinção que tornava a democracia dos modernos diferente da democracia dos antigos. Tocqueville foi quem, pioneiramente, fez esta distinção. As observações de Benjamin Constant são exemplares para o argumento que me disponho a produzir.

Constant, apesar de ser defensor da democracia representativa, foi o primeiro a perceber que o porte de direitos não significa necessariamente seu exercício (Bobbio, 1990) pelo simples fato de que a complexidade da sociedade moderna oferta direitos ao cidadão como prerrogativas, para usar um termo de Darhendorf. Mas o exercício destas prerrogativas não é compulsório, imperativo.

Nas modernas sociedades de massa, é simplesmente impossível imaginar a vida de um cidadão no exercício pleno de seus direitos políticos. Direitos políticos e civis são direitos emancipatórios, são possibilidades que se abrem para o indivíduo, que, autonomamente, decide sobre seu usufruto ou não.

Portanto, como direitos de liberdade, não cabe um outro emitir julgamento sobre a escolha individual. Portanto, a decisão, pessoal, de não exercer um direito político, optando por uma ampliação da vida privada, como sugeria Constant, não significa o abrir mão de um direito; pelo contrário, trata-se de uma decisão individual de quem se utiliza de uma prerrogativa, entendida como liberdade.

A chamada democracia dos modernos produz também uma nova concepção de liberdade. Se na antiga democracia ateniense a liberdade era concebida como o poder de participar das decisões do estado, de julgar e decidir sobre a guerra e a paz, na democracia dos modernos a liberdade é entendida, principalmente, como o exercício pleno dos direitos civis. A noção moderna de liberdade entende o direito de ir-e-vir, o direito de escolher, o direito à privacidade, o direito de não ser preso, de não ser torturado. Enfim, a liberdade era vista pelos antigos como alguma coisa vinculada à esfera pública, enquanto para os modernos o conceito de liberdade é hoje nitidamente vinculado à esfera privada.

$\mathrm{Na}$ lógica moderna de liberdade são, portanto, os direitos civis que consagram a liberdade e a autonomia do indivíduo na esfera privada, enquanto os direitos políticos referem-se explícita e exclusivamente à esfera pública. Isto quer dizer que, para os modernos, os cidadãos são livres para se ocuparem com seus afazeres privados e com sua vida pessoal e profissional posto que o poder político é exercido, em seu nome - ao menos teoricamente -, por representantes por eles eleitos para esta finalidade.

Neste ponto surge uma questão que nos interessa especialmente: o processo por meio do 
qual realiza a livre escolha dos representantes. Esta pressupõe, conforme Norberto Bobbio, para que a democracia representativa se concretize e para que o processo da representação se realize de fato, duas premissas básicas. A primeira estabelece que aqueles que desejam ser votados tenham ampla liberdade de manifestação, expressão e organização partidária. A segunda dita que aqueles que vão escolher os seus representantes façam a sua escolha sem constrangimento de todas as alternativas colocadas em disputa (Bobbio, 1986). Retomando o raciocínio inicial, observa-se claramente que quanto mais tais circunstâncias se concretizem, tanto mais democrática a democracia (Bobbio, 1986). Vale lembrar ainda que estas duas situações citadas não se apresentam apenas de uma forma absoluta. Tais premissas são não apenas imprescindíveis, como aperfeiçoáveis. A liberdade de expressão de quem disputa o voto e a liberdade de escolha de quem vota são ocorrências que, a despeito de existirem ou não, podem ser julgadas e avaliadas a partir de níveis de gradação variáveis.

A liberdade de manifestação e expressão do pensamento, como direito civil, é um direito que surge exatamente para permitir, na norma jurídica, a livre circulação de idéias através dos jornais e da imprensa em geral. É um direito que toma forma em todo o mundo ocidental e se consagra nos Estados unidos, através da Primeira Emenda da Constituição. Resolve, pela norma jurídica, apenas o primeiro aspecto da questão. Uma vez que a liberdade de imprensa permite, na lei, a cada um falar e expor suas idéias com liberdade, torna-se necessário, para a construção de uma efetiva democracia, dar resposta, também, ao segundo aspecto da questão, ou seja, resolver como fazer com que cada um, cada eleitor individualmente, escolha entre as diversas alternativas em disputa com plenas condições de acesso a todas elas.

Além disso, uma terceira questão aparece. Como já vimos, os direitos civis não igualizam direitos: os homens não são iguais para montar jornais e defender suas idéias.

Tudo isso faz com que os procedimentos da democracia, para se realizarem, necessitem de diversos processos sociais de mediação, caracterizando, assim, as especificidades do chamado direito à informação. Já neste aspecto aparece visível que o direito à informação não é, como os outros direitos que vimos anteriormente, um direito-fim, um direito que se realiza em si

\section{mesmo.}

O direito à informação, portanto, é um direito-meio, é um pressuposto, neste caso, para que o direito político se realize em melhores condições. Se, por exemplo, todos os cidadãos não forem informados sobre todas as alternativas em disputa numa determinada eleição, esta eleição passa a contar com um vício de origem que, embora não a desqualifique como antidemocrática, a torna menos democrática.

o ordenamento jurídico permite a classificação dos direitos relativos à esfera pública: liberdade de opinião e de expressão, liberdade de imprensa, liberdade de reunião e associação. Estes direitos podem ser organizados em relação à função política de pessoas privadas na esfera pública: direito de petição, direito eleitoral e de voto igualitário. Um terceiro grupo de direitos, referentes ao intercâmbio dos proprietários na esfera privada, dizem respeito à liberdade individual da pequena família patriarcal: liberdade pessoal, inviolabilidade de correspondência, igualdade perante a lei, garantia da propriedade privada.

Os direitos civis fundamentais ordenam as esferas pública e privada, as instituições e instrumentos do público (imprensa, partido), a base da autonomia do privado (família, propriedade), as funções políticas dos cidadãos e as econômicas dos proprietários de mercadorias. (Habermas, 1984)

O ordenamento jurídico constitui-se de regras e procedimentos que vão definir como os conflitos serão resolvidos e devem, necessariamente, prever mecanismos pelos quais as opiniões e os interesses antagônicos, contraditórios ou conflitantes devem se expressar com liberdade.

Ora, se o que caracteriza a democracia contemporânea é exatamente a existência de princípios e de regras que estabelecem quem está autorizado a tomar as decisões coletivas e com que procedimentos, (Bobbio, 1986) então, do ponto de vista estritamente formal, é a norma jurídica, de uma maneira ampla, que vai definir a gradação democrática de uma determinada sociedade.

Esta base consensual, sobre a qual se assentam as regras e os procedimentos, deve se constituir, necessariamente, num consenso preexistente, onde indivíduos de todas as classes, sexos, culturas, interesses, regiões, religiões, etc., possam expressar suas opiniões, lutar por elas e por seus interesses num ambiente no qual 
prevaleça a convivência e a tolerância com a diferença.

A conquista deste "consenso" no pluralismo, na diversidade e na tolerância com a diferença não foi algo imposto autoritariamente ou conquistado pela adesão geral a tais "valores universais". Foi, pelo contrário, o resultado dos conflitos e tensões concretos da sociedade, nos quais nenhum desses grupos foi capaz de impor uma dominação total sobre os outros. Os dois grandes - mas não apenas eles - campos de idéias que marcaram a evolução da sociedade moderna, o liberal, no qual prevalecia a necessidade sobre a liberdade, ambos herdeiros da tradição iluministas, foram produzindo, por suas ações e lutas, os direitos de cidadania e as regras e procedimentos para solucionar suas diferenças.

Alberto Hirschmann, em seu A Retórica da Intransigência, observa que "se reconhece cada vez mais que, tipicamente, os regimes pluralistas modernos não surgiram devido a um amplo consenso preexistente acerca dos "valores básicos", mas antes porque vários grupos que estivera em pé de guerra por um longo período foram forçados a reconhecer sua incapacidade mútua para alcançar a dominação. A tolerância e a aceitação do pluralismo acabaram resultando de um empate entre grupos opostos visceralmente hostis" (Hirschaman, 1992, p. 139).

Aliás, visto de um outro ângulo, infelizmente pudemos ver, nas experiências totalitárias do século $X X$, os lamentáveis e trágicos exemplos de momentos históricos em que um "grupo" impôs a sua vontade sobre os demais (Veca, 1990).

O problema do pluralismo é decisivo. Ele pressupõe uma pluralidade de grupos independentes e com funções limitadas que sustentam a democracia liberal, proporcionando bases sociais de concorrência livre e aberta pela liderança, participação generalizada na seleção dos líderes, restrição da aplicação da pressão sobre os líderes e autogoverno em vastas áreas da vida social. Daí a conclusão: "Onde o pluralismo social é forte, a liberdade e a democracia tendem a ser fortes; $\mathrm{e}$, inversamente, as forças que enfraquecem o pluralismo social também enfraquecem a liberdade e a democracia"4.

A democracia, assim, consolida-se como o resultado deste "empate", institucionalizase como o mecanismo através do qual todos os diferentes encontram mecanismos de expressão de seus interesses e opiniões. Este, o sentido maior de sua compreensão como "valor universal". Temos aí, também, o ponto central, a base sobre a qual se assenta, concretamente na sociedade, a prevalência da liberdade sobre a igualdade tratada no capítulo anterior. A cogência, à qual me referi anteriormente, assume, agora, uma concretude efetiva. É sobre este campo que se estabelecem os conflitos e é nele que se batalham por idéias e opiniões ou estabelece-se a luta política pela "paixão democrática" defendida por Pietro Barcelona.

A esfera pública passou a se constituir no princípio organizador da sociedade moderna, na medida em que os debates parlamentares, os processos judiciais e as administrações executivas requereram publicidade para que se estabelecessem conexões entre estrutura de poder e cidadãos e para que fossem controlados. O caráter de "emanação do poder do povo" está vinculado a um acesso de todos ao poder que, mesmo incompleto, supõe uma antecipação de direitos. O público do estado burguês também se constitui enquanto sujeito e não só enquanto cidadão.

O homem transformou-se em "ser humano", ou seja, desenvolveu esta concepção de si mesmo(Habermas, 1984).

Desde o último cartel do século XIX a esfera pública burguesa vem sofrendo uma progressiva refuncionalização, onde o privado e o público se interpenetram a partir de um progressivo intervencionismo estatal na economia, transcendendo a originária separação estadosociedade, surgindo entre ambas uma esfera social politizada, que não pertence nem ao público nem ao privado. O movimento de oligopolização de poderes na esfera privada, que por sua vez, repercutiu na intensificação das funções estatais, que o capitalismo passou a exigir do estado (Habermas, 1984) fins do século $X X$, tal projeto modernista ${ }^{5}$ se complexifica de tal forma que coloca problemas e dificuldades de natureza até então desconhecida para se estabelecer novos direitos. A nova feição do mundo demanda uma perspectiva essencialmente pluralista para comportar a fragmentação dos valores, decorrentes dos atuais conflitos e tensões, definidores de um dos desafios contemporâneos mais decisivos.

A realidade que se apresenta a partir dos anos 80 coloca o mundo frente a problemas até então desconhecidos: ambientais, migrações em massa para países desenvolvidos, 
realidades técnico-econômicas mais complexas e diferenciadas, crise política nos países do Leste Europeu, estagnação econômica e inflação permanente, expansão do gasto público, sobretudo nos países mais pobres. A implicação destes problemas em termos internacionais está assentada na lógica do subdesenvolvimento que coloca a todos numa interdependência planetária, redefinindo as relações internacionais numa dimensão muito mais complexa em termos mundiais. $^{6}$

Além disso, temas emergentes como engenharia genética, inteligência artificial, informação e tecnologia energética afloram e passam a compor uma agenda de assuntos desafiadores da produção de novos direitos (Veca, Salvatore, op. cit.). Tudo isso faz com que alguns cheguem a conceber o homem como "co-inquilino do planeta"7 ou "cidadão do mundo" (Cerroni, Umberto, 1991) e partidos progressistas criados para agir neste novo ambiente incluem em seu programa a idéia do "governo mundial".

Todas estas formulações estão atentas para a necessidade de elaborar um novo direito internacional que amplie a incorporação dos cidadãos na órbita dos Estados nacionais, que se assente sobre a preservação das culturas nacionais, que promova uma nova cultura verdadeiramente aberta e coletivamente controlada, que favoreça formulações intelectuais mais pluralistas e tolerantes.

Esse raciocínio induz à formulação de que é a partir das regras da democracia formal, pela via da conquista de maiorias e da implementação de fortes reformas que se caminhará na direção de conquistas e ampliações efetivas de direitos rumo a uma efetiva democracia de massas. $A$ consagração da democracia política como forma de organização social é um dos elementoschave do raciocínio (Bobbio, 1986). É, portanto, o "regime do poder público em público", ou "o regime do poder visível" (Bobbio, 1986).

Se é verdade que produzir uma democracia de massaé o desafio do mundo contemporâneo, então, este desafio poderá, ou não atingir seus objetivos, de um lado, pelo processo de criação e consolidação de direitos de cidadania e, de outro, pela imposição da "paixão democrática" proposta por Barcelona.

Portanto, uma das premissas de uma sociedade democrática, que torna a sociedade mais democrática, é, conforme Salvatore Veca "o igual direito dos cidadãos ao acesso a uma informação pluralística, na sociedade na qual a produção e o consumo de informações tenham uma particular relevância" (Veca, 1990). Este é, exatamente, o problema a ser enfrentado teórica e praticamente. Como conceber, nas modernas sociedades de massa, um modelo de estrutura de comunicações que seja pluralista, livre, amplo e acessível à população.

Tomo como ponto de partida uma constataçãobanal:contrariamenteaoqueocorria no passado, é absolutamente inconcebível, nos dias que ocorrem, imaginar a possibilidade de vida nas modernas sociedades de massa sem a mediação informativa do jornalismo.

A informação jornalística é, simplesmente, indispensável para o estar no mundo nos dias de hoje. O que alguns autores chamam de "necessidades sociais da informação" é hoje suprida sobretudo pelo jornalismo. Não se quer dizer com isso que seja impossível a vida em sociedade sem o consumo da informação jornalística produzida pelas mídias. Mas a realidade é que todas as informações indispensáveis para a vida em sociedade chegam, hoje, aos homens, de forma mediada e não direta. Dois exemplos são suficientes: 1as informações sobre saúde pública alcançam o conjunto dos cidadãos por meio das mídias. 2os candidatos a uma eleição não buscam o voto por meio de uma relação direta com o eleitor.

A cidadania requer, conforme a avaliação clássica de Marshall, "um sentido direto de inclusão numa comunidade, baseado na lealdade a uma civilização que é propriedade comum"?.

Desnecessário afirmar a importância do papel desempenhado pelos meios de comunicação nestes processos de integração sociais, sobretudo nas complexas sociedades de massas do presente. Portanto, a discussão recente que qualifica as sociedades contemporâneas como midiáticas é correta e acerta no essencial.

Com efeito, se as modernas sociedades de massas são marcadas pela posse de direitos, na sua complexidade coloca a exigência da ampla difusão de informação e cria a necessidade de se tornar claro e preciso o sentido do conceito "direito à informação". O papel da comunicação de massa na difusão e propagação desta "civilização que é propriedade comum", assim, é inquestionável.

Sintomático, no entanto, que toda a bibliografia teórica e específica sobre o conceito da cidadania não faça referência ao direito à 
informação. Trata-se, é verdade, de um direito secundário, no sentido de que é um direito necessário para a realização de outros direitos, um direito "meio", não um direito "fim". Igualmente sintomático também, por outro lado, seu oposto: a bibliografia que trata das questões do direito à informação ou mesmo da liberdade de imprensa não se apóia em obras que contextualizam a discussão no debate em torno do conceito de cidadania.

Grosso modo, na maioria dos textos mais recentes que tratam do assunto trabalha-se de maneira imprecisa com o conceito de "direito à informação", ou, mais imprecisamente ainda, com o termo "direito social à informação". Evita-se definir e aprofundar o conceito e se o toma, na maioria dos casos, meramente como uma ampliação do conceito de expansão da cidadania, numa lógica mecânica. Norberto Bobbio e Hannah Arendt, assim como, aqui no Brasil, João Almino, pensadores que têm em comum o fato de se apoiarem basicamente na filosofia e de fugirem das camisas-de-força ideológicas, são algumas das exceções que tratam do assunto, embora não com ênfase que o assunto faz hoje por merecer. Vale lembrar, também, a obra do brasileiro Celso Lafer, comentador de Hannah Arendt, que, em seu trabalho, sistematiza o pensamento da autora alemã sobre a questão ${ }^{10}$. Estes autores com os quais pretendo trabalhar são praticamente ignorados nos trabalhos sobre o "direito à informação".

A democracia moderna é, no dizer de Norberto Bobbio, a "sociedade dos cidadãos", noção que diz respeito à ampliação e ao alargamento dos direitos civis, políticos e sociais. Esta "sociedade dos cidadãos" é definida por Bobbio, também, como "a democracia do poder visível" ou "o governo do poder público"(Bobbio, 1986).

Nestas formulações, o autor se refere explicitamente ao imperativo democrático de dar publicidade àquilo que é público, de tornar público, visível, transparente, os fatos relativos à esfera pública. Norberto Bobbio demonstraainda como apenas aparentemente a formulação é paradoxal, já que público é oposto igualmente a privado e a secreto. Nesta interpretação original de Bobbio, é possível entender "poder público em público", ou seja, como o governo em que "aquilo que não é privado não é secreto"(Bobbio, 1986).

Implícito no seu raciocínio a compreensão de que, para se ter acesso ao poder público - e, por conseqüência, à posse de direitos -, o cidadão precisa ter assegurado o acesso à informação pública. Esta é, também, uma das condições para a ampliação dos direitos. Os direitos civis e políticos, direitos que se configuram como prerrogativas e pressupõem a liberdade de escolha do cidadão, são direitos que se alargam, de uma maneira evidente, com o acesso à informação.

Para Dahrendorf, como vimos, os direitos de cidadania modernos são divididos em "prerrogativas" e "provimentos". Os direitos civis e políticos constituiriam-se em prerrogativas queas legislações devem garantir a todos os cidadãos e os direitos sociais se inserem no âmbito dos programas e políticas de governo, porque se referem a "provimentos", a determinados setores sociais, a serem garantidos ou regulados pelo Estado ${ }^{11}$.

Tal compreensão pode ser vista como desenvolvimento do raciocínio que entende o direito civil como um direito que protege o cidadão do poder do Estado, o direito político como aquele que estabelece os mecanismos de participação no Estado e os direitos sociais como direitos a serem garantidos pelo Estado.

O direito à informação, portanto, deve ser compreendido como um direito relacionado diretamente aos outros direitos, incluindo, obviamente, as contradições e os antagonismos destes.

É um direito que fomenta o exercício da cidadania necessário ao exercício pleno do conjunto dos direitos de cidadaniae, portanto, um fator decisivo no processo de aprofundamento democrático. Como conseqüência do raciocínio, o entendimento de que o acesso à informação é uma porta de acesso a outros direitos: numa sociedade de massas moderna, o acesso à informação jornalística, por parte do cidadão, pode potencialmente vir a consistir num direito que assegura outros direitos, confere condições de igualização de sujeitos e oferece a visibilidade ao poder e ao mundo.

O direito à informação é, portanto, um direito em si - a despeito de se configurar como um direito-meio - e assim deve ser compreendido em toda a complexidade que envolve os direitos nas sociedades modernas. É, também, e esta é uma questão central, a porta de acesso a outros direitos. Nas sociedades modernas, estruturadas como democracias representativas, como já visto, todos os direitos 
em alguma medida relacionam-se com o direito à informação: o alargamento da participação na cidadania pressupõe um alargamento do direito à informação como uma premissa indispensável, um pressuposto.

A reflexão neste ponto interessa particularmente: se éreal o desafio da construção de uma democracia de massas, então é forçosa a admissão do ser humano como um ente emancipado, capaz de avaliar e julgar todas as questões públicas de forma autônoma, sem tutela, com independência absoluta. O princípio do julgamento individual torna-se, assim, uma premissa para uma efetiva democracia de massas. Este raciocínio tem o sentido de que, para a democracia, vale o reconhecimento do conjunto, ou melhor, da totalidade dos julgamentos individuais, mesmo que este julgamento se realize sem o rigor do juízo dos pensadores profissionais como filósofos e cientistas (Lafer, 1988). Vale dizer que os homens, numa democracia, precisam todos igualmente expressar vontades e interesses (que podem ser vistos tanto como privados e, portanto, ilegítimos; como também como resultantes da diversidade social), como também efetivamente juízos como a expressão maior da dimensão pública dos direitos civis ampliados e alargados para todos numa sociedade de massas.

Seja na expressão de vontades ou interesses, seja na expressão efetiva de um juízo, a igualdade de todos no valor de seu julgamento é um dado indispensável para a democracia. Ora, se uma democracia de massas é a democracia mais democrática possível, então, as condições para um juízo efetivo de todos os cidadãos tornam-se um imperativo. É neste contexto, de fornecer as condições para um juízo do cidadão, que se deve pensar o conceito de "direito à informação". A questão pode ser vista a partir de duas vertentes:

1) O direito à informação deve ser pensado na perspectiva de um direito para todos.

2) $O$ direito à informação deve ser pensado na perspectiva de fornecer informações em quantidade e qualidade para o melhor julgamento possível de cada um. Volto a esta reflexão mais adiante.

Como já mencionei anteriormente, as reflexões tradicionais sobre cidadania praticamente não fazem referência ao direito à informação. $\mathrm{Na}$ verdade, isto se dá porque são reflexões que tratam dos, por assim dizer, "direitos-fim", dos direitos de cidadania no seu sentido estrito. O acesso à informação é, para o tipo de argumentação que desenvolvo aqui, um "direito-meio", no sentido de que é um direito sem o qual os outros direitos ficam prejudicados. Por esta compreensão, é a porta de acesso pleno aos demais direitos.

Com a expressão "direito-meio" estou querendo dizer que o direito à informação não se realiza em si mesmo, não se concebe a informação como algo com valor em si mesmo. Inclusive porque falar apenas em direito à informação esclarece pouco. Direito à qual informação? O direito à informação concebido como o direito de cidadania é, exatamente, o direito àquelas informações necessárias e imprescindíveis para a vida numa sociedade de massas, aí incluindo o exercício pleno do conjunto de direitos civis, políticos e sociais. Antagônico ao direito à informação temos o direito à privacidade, isto é, o direito de permanecer secreto - isto é, sem visibilidade pública - tudo aquilo que se refira ao campo da intimidade, a saber, a esfera privada.

O direito à informação, assim, deve ser pensado como o direito que inclui necessariamente as condições necessárias para realizar as escolhas concernentes ao exercício pleno dos direitos. O direito de cada um ter acesso às melhores condições possíveis para poder formar as próprias preferências particulares, fazer suas escolhas e seus julgamentos de modo autônomo. Nestas condições é uma circunstância que gera um direito à autonomia; é, portanto, um fator de mão dupla no processo de emancipação humana na medida em que auxilia o cidadão no exercício de suas prerrogativas, por outro, consolida o conjunto dos demais direitos posto que sua difusão, ao se tornar mais ampla, torna-se por conseqüência mais acessível.

Estabelecendo um paralelo entre as peculiaridades do direito à informação e as características dos direitos de cidadania, verificase uma complexa interconexão que merece ser melhor esclarecida. É disso que tratamos a seguir.

O direito à informação pode ter características emancipatórias ou de tutela. Direito emancipatório é um direito de liberdade, é um direito cujo pressuposto básico é a liberdade de escolha, uma "prerrogativa", no entendimento de Darhendorf.

Direito à informação com características emancipatórias é o direito às informações 
concernentes aos direitos civis ou políticos. Direito de tutela, por outro lado, é um direito vinculado aos direitos sociais, ou seja, trata-se daquela informação que ou torna públicos os direitos sociais ou se constituem elas mesmas no próprio direito social.

Mostro como exemplo, para esclarecer o argumento, o acesso à saúde e à escola. A informação sobre as possibilidades deste acesso potencializam de forma direta este direito. Noutra perspectiva, a difusão de uma informação de interesse social - por exemplo, a difusão ampla da fórmula do soro caseiro se constitui numa informação que se constitui, ela mesma, o próprio direito numa perspectiva social. Como já foi visto, trata-se de um direito a ser exercido ou regulado pelo Estado.

A informação como direito social é, portanto, toda aquela informação, de sentido social, indispensável para a vida em sociedade. Toda aquela informação concebida à semelhança da educação, como o repasse de informação indispensável para um uso coletivo das conquistas humanas no campo social. O direito à informação na perspectiva social deve ser concebido como uma extensão do direito à educação e do direito à saúde, necessárias e úteis para a manutenção da vida humana em sua dignidade mínima.

É neste entendimento que a informação deve ser concebida como um provimento, da mesma forma como o direito social em si.

O cidadão não tem o direito de escolher entre receber ou não uma informação, como tem a prerrogativa de andar livremente pelas ruas, se assim o desejar. O cidadão tem o direito de ser provido das informações necessárias para o seu dia-a-dia, assim como um pai, que tem a obrigação de levar o seu filho ao posto de vacinação, tem o direito de receber as informações necessárias para que cumpra com esta obrigação sem dificuldades.

Informação sobre saúde e profilaxia, formas de prevenção de doenças, informações sobre reidratação oral, sobre mecanismos para evitar a meningite ou o cólera ou sobre a Aids, informações sobre campanhas de vacinação, devem ser concebidas nesta dimensão. O jornalismo é uma das formas de expressão deste direito social. Obviamente não a única. Nos momentos em que se manifesta a carência do cidadão no acesso a estas informações, cabe ao Estado oferecer tais informações, de forma tutelar ou regulamentar, da mesma forma como fornece (ou deveria fornecer) saúde, educação ou outros serviços sociais.

Assim, o acesso à informação necessária para o exercício de um direito social deve ser, portanto, provido, concedido ou regulado pelo Estado. Aameaça de uma calamidade pública ou de uma epidemia seria um exemplo dramático de uma dessas situações extremas em que o Estado tem a obrigação de prover o cidadão das informações que ele tem direito para que tome as providências necessárias para enfrentálas. Assim, campanhas de esclarecimento sobre a Aids ou sobre os cuidados necessários à prevenção do cólera devem ser produzidas pelo Estado. Estes são casos típicos em que a informação é um direito social. ${ }^{12}$

O fato do direito à informação como um direito social ser vinculado ao Estado não significa que tal seja exclusivo do estado. Os meios de comunicação, como instituições livres - jornais e revistas - ou como concessões públicas - TVs e rádios -, são livres para produzir informação deste tipo.

Evidentemente, a regulação estatal é recomendável. ${ }^{13}$ Não é preciso muito esforço, portanto, para compreender que o acesso aos provimentos se amplia quanto maior for o número de pessoas que tiverem informação sobre o direito a estes provimentos.

É neste sentido que Barbalet afirma que os direitos sociais, ao contrário dos direitos civis e políticos não são universais, mesmo porque, como já foi visto, se referem não ao cidadão, mas ao "trabalhador", ao "idoso", à "criança", etc.(Barbalet, 1989). Em alguma medida são direitos vinculados a algum tipo de obrigação ou regulação do Estado. São direitos onde o direito de escolha sofre, sempre, algum tipo de limitação, e, às vezes, uma limitação total. Assim, na perspectiva social, o direito à informação pode admitir restrições. São inúmeros os casos de conflito entre a liberdade de manifestação e expressão e a regulação de proteção à criança e ao adolescente. ${ }^{14}$

Podemos ver o direito à informação na perspectiva social, assim, sob duas abordagens. Numa ele deve ter o sentido universal, de propagar, a todos, os benefícios conquistados pela civilização, com ênfase especial nas áreas de saúde, educação ou assemelhadas. Embora não propriamente impositivo - mesmo porque se trata de um direito - ele é um direito concernente a todos, vistos como cidadãos emancipados. Noutra abordagem, ele é restritivo e limitador, 
particularmente ao atingir segmentos sociais por alguma razão ainda não emancipados como cidadãos plenos, como, por exemplo, a criança e o adolescente, entre tantos outros "personagens como sujeitos de direitos", já vistos no capítulo anterior.

Nos elementos em que se confunde com outros direitos, como visto em algumas características, o direito à informação, na perspectiva social, tem as características de direito do consumidor.

Informação como direito civil é a forma como se manifesta presentemente a liberdade de manifestação e de expressão no contexto do estado de direito. Na verdade, o direito civil à informação é apenas um aspecto específico do conjunto dos direitos civis que são muito mais amplos. Ela se baseia sobretudo no direito de dizer, no combate à qualquer tipo de censura, na liberdade de se criar jornais, difundir informações, etc.

Como prerrogativa civil, o direito à informação assume também a premissa básica da plenitude dos direitos de escolha, pelo fato de pressupor que cada um possa se inserir, como unidade independente, "com meios para proteger a si mesma" (Barbalet, 1989) uma vez que os direitos civis se constituem em direitos de liberdade.

Embora em circunstâncias diferentes, os direitos civis também são direitos que se alargam com o acesso à informação. Neste caso, o acesso à informação também é apenas uma prerrogativa. Mas quando associamos a idéia do exercício do direito civil a uma circunstância de amplo acesso à informação, fica claro o entendimento da relação de causa e efeito entre, por um lado, a idéia de direitos que geram direitos, e por outro, o fato de que os direitos civis são direitos que assumem outra qualidade quando efetivamente universais. ${ }^{15}$

Vale lembrar, com destaque, que se há grande desigualdade de direitos civis entre o cidadão comum e o proprietário, tal desigualdade atinge o paroxismo se o proprietário for possuidor de um veículo de comunicação de massa. De todo modo, como tratarei a seguir, isto não pode ser visto de uma maneira absoluta, conforme será esclarecido no próximo capítulo.

O direito à informação na perspectiva política, por sua vez, deve ser entendido sob outra abordagem. Há dois grandes ângulos de visão. De um lado, deve ser entendido como a informação que permita ao cidadão a escolha, a opção, no campo da esfera pública. A visibilidade do poder e das possibilidades de escolha deve ser entendida como uma das premissas do direito à informação na perspectiva política. Tem um sentido nitidamente distinto do direito social.

Os direitos políticos, assim como os civis, são direitos relativos à liberdade, são prerrogativas, enquanto que os sociais o são à necessidade, são provimentos. No caso do direito político, as liberdades civis apresentam-se, portanto, como uma das premissas (entre duas) necessárias para o seu pleno usufruto.

No campo dos direitos políticos, o direito à informação é um direito imprescindível sobretudo para o exercício pleno e consciente do direito de voto. Se o cidadão não tiver acesso às informações necessárias sobre os partidos em disputa, suas propostas, suas opiniões, etc., ele não poderá votar conscientemente.

$\mathrm{Na}$ verdade, o direito de voto é apenas uma das condições - a mais essencial - do direito político. Além desta, o acompanhamento sistemático das atividades do governo, dos movimentos e discussões do parlamento, dos comportamentos dos atores políticos em geral, enfim, a publicidade dos atos do governo, são outras condições indispensáveis para o exercício permanentemente das prerrogativas políticas e só são possíveis a partir da difusão de informações. Trata-se de um papel imprescindível para o exercício dos direitos políticos aqui assinalados de forma mais do que evidente.

Sob um outro ponto de vista, o acesso à informação é uma prerrogativa e deve ser garantido porlei. Isto porque odireitoà informação necessária para o exercício de uma prerrogativa deve se constituir numa prerrogativa, da mesma forma que, como vimos, o direito à informação necessária para o exercício de um direito social deve ser um provimento. Em defesa deste argumento podemos argumentar tomando o caso, por exemplo, da muito bem concebida legislação brasileira sobre comunicação partidária e eleitoral.

O Brasil conta com monopólios de comunicação de massa muito consolidados na mídia eletrônica. No entanto, como concessões do Estado, eles são obrigados por lei a abrir mão de seus horários mais lucrativos16 às vésperas de eleições para que cada corrente política veicule, com total liberdade, e na proporção de suas forças nos parlamentos, as suas idéias e propostas. Eis aí uma formulação legal que 
equilibra e soluciona uma situação de um conjunto de direitos em conflito.

Por um lado, todos os cidadãos são providos das informações necessárias para fazerem as suas opções políticas com o máximo de informação possível. Por outro lado, cada partido político não apenas é livre para expor suas idéias, mas dispõe de um determinado tempo de veiculação nos meios eletrônicos. A desigualdade dos iguais no exercício do direito civil de liberdade de opinião é neutralizada pela lei.

Neste caso, o único acerto ainda a ser feito é deixar de ser compulsório, mesmo porque, se o direito político se constitui numa prerrogativa, o direito à informação política também deve sê-lo. Portanto, é inconcebível que se constitua numa obrigação. Da mesma forma, o cidadão deve ter livre o seu acesso às informações necessárias à sua decisão política, mas não em redes que obstruam o seu direito de optar pelo lazer, pela novela ou por qualquer outra programação. Neste caso, se ninguém é obrigado compulsoriamente a manter o televisor ligado durante as transmissões em rede, podendo fazer qualquer outra atividade, não há razão que justifique o fato de que ele pode fazer qualquer outra coisa menos optar por uma outra programação da TV. ${ }^{17}$

Como direito, o direito à informação é sobretudo um direito político, embora tenha algumas especificidades do direito civil e outras, de direito social. Em todas elas, trata-se de um direito relativo explicitamente à esfera pública. E como um direito relativo à esfera pública, tem como limites exatamente o direito à privacidade. Estaé uma questão que exige um esclarecimento mais detalhado: de um lado, como expressão da liberdade de manifestação e expressão, o conflito com o direito à privacidade trata-se de um conflito entre dois direitos civis.

Evidentemente, é preciso pensar o direito à informação também como um dever (ser) público ou dever (ser) privado. A distinção, cara a T. H. Marshall, recupera a discussão de cidadania para o seu sentido original e permite que entendamos o direito à informação nos seus vários aspectos. O contraponto do direito à informação é o direito à intimidade. Tudo aquilo que se relaciona à esfera privada "não exige publicidade porque não envolve direitos de terceiros" (Lafer, 1988).

Os direitos individuais tradicionais se inscrevem na esfera das liberdades. São direitos que se referem a uma afirmação de liberdade coercitiva em relação à autoridade estatal. São direitos que exigem obrigações por parte de outras pessoas, incluindo os órgãos públicos, abstenções de determinados comportamentos, que venham a ferir tais direitos. Para que o direito à privacidade encontre proteção e reconhecimento como direito civil e privado, precisa ser protegido pela legislação e/ou pela ética - entendida aí como deontologia.

Aí está o ponto fulcral no conflito entre o direito à privacidade e a liberdade de manifestação de expressão e pensamento. Ambos se constituem em direitos civis, e possuem as características a que me referi. São, no entanto, conflitantes entre si. À medida que os direitos sociais ganhem reconhecimento, transformam-se em poderes (Bobbio, 1992). Se houver um reconhecimento do direito de privacidade como uma exigência da ética jornalística, este direito passa a se transformar em poder de coibir o jornalista individualmente a exercer sua liberdade individual de tornar públicas informações da esfera da privacidade. Caso contrário, a informação privada transformase em informação pública. E é exatamente em torno deste conflito que se situa o nó górdio da ética da informação: distinguir e separar a esfera pública daquela privada. Assim, a liberdade de manifestação e expressão deve ser total na esfera pública, onde é inaceitável qualquer tipo de censura ou cerceamento.

Assim, a máxima que poderia resumir a questão ética do direito à informação seria: dar o máximo de publicidade a tudo o que se referir à esfera pública e manter secreto tudo aquilo que se referir à esfera privada. A produção da visibilidade do poder, ou a publicização do governo, é a razão de ser da imprensa. Como fazê-lo, num mundo onde a distinção entre público e privado cada vez mais se dilui, onde são crescentes os fenômenos de publicização do privado e privatização do público?

Ainformação sobre a privacidade alheia não pode ser concebida como um direito, embora o seu cerceamento se constitua numa limitação à liberdade de manifestação e expressão, o que caracteriza um conflito entre dois direitos civis:

Poderia-se argumentar, como o fazem, aliás, os donos de jornais, que, neste caso, o caráter público do direito prevalece sobre o privado. Tal ocorreria apenas em circunstâncias especiais, conforme o entendimento de Norberto Bobbio. Se um dirigente de um órgão 
público usa recursos públicos para atividades privadas, este sim seria um dos casos em que haveria prevalência do público sobre o privado. (Bobbio, 1987). Tal circunstância faz com que, na prática jornalística, a discriminação entre informação pública e privada tenha se tornado uma grande dificuldade para a efetiva proteção dos direitos de privacidade do cidadão (que origina a informação) e do direito à informação pública dos cidadãos a quem se destinam às informações.

Fazendo uma analogia à necessidade de proteção do direito civil contra a afirmação coercitiva do Estado, vê-se que o direito à privacidade depara-se com o paradoxo de precisar encontrar uma proteção mais efetiva contra a autoridade privada conferida socialmente ao jornalismo, de tornar pública a informação que é da esfera privada.

\section{Notas}

1 No Brasil, há uma confusão neste sentido. Na época da ditadura militar, quando o general Figueiredo, numa entrevista, comparou a democracia a laranjas, mostrandoque poderiam existir democracias de vários tipos, a oposição, corretamente, afirmou que democracia é democracia e ponto final. A frase era correta apenas conjunturalmente, posto que vivíamos numa ditadura e 0 argumento do general era 0 de forçar uma situação tentando caracterizar o regime ditatorial como democracia. 0 acerto conjuntural consistia na clareza que as oposições tinham de que a conquista de um mínimo de procedimentos democráticos era a tarefa fundamental no momento. Democratizar a democracia era uma tarefa que só podia ocorrer concretizada a primeira parte.

2 Compreendemos pobreza aqui na acepção de ARENDT, Hannah. - Da Revolução.. p. 48. "Pobreza é mais do que privação, é um estado de constante carência e aguda miséria, cuja ignomínia consiste em sua força desumanizadora; a pobreza é abjeta porque submete os homens ao império absoluto de seus corpos, isto é, ao impérrio absoluto da necessidade, como todos os homens a conhecem a partir de sua experiência mais íntima independente de todas as especulações".

3 Esta formulação aparece problematizada em Dahrendorf, Veca e Bobbio, entre outros.

4 KORNHAUSER, the politics of Mass Society, PP 230-231. apud SWINGEWOOD, Alan. - op. cit. p. 19.
50 termo modernista é entendido aqui no sentido formulado por BERMAN, Marshall. - Tudo que é sólido desmancha no ar, São Paulo, Companhia das Letras.

6 CERRONI, Umberto, "la ricomposizione Del moderno. Um nuovo racionalismo". In: Rinascita, n7, Nuova serie, anno II, 24 febbraio 1991, pgs 40-47.

70 conceito de cidadão do mundo é desenvolvido a partir da idéia kantiana do "direito cosmopolítico"conforme VECA, Salvatore. op. cit. p. 57.

8 Tal idéia encontra-se formulada explicitamente no programa do novo Partido Democrático della Sinistra, na Itália. Ver no texto do esboço de programa publicado em Rinascita, nuova Série, anno I, 16 settembro 1990 pgs. 35-49.

9 MARSHALL, T. H. - apud BARBALET, J. M. - A Cidadania, op. cit. p.107.

10 LAFER, Celso. - A Reconstrução dos direitos humanos: um diálogo com o pensamento de Hannah Arendt, São Paulo, Companhia das Letras, 1988, 406 pp.

\section{LAFER, Celso. -op. cit. p. 288.}

12 Neste caso, é útil e exemplar lembrar as quase duas mil mortes por meningite provocadas pela

ausência forçada de informações devido à censura do governo militar, no início dos anos 70 no Brasil. Ver, por exemplo ABRAMO, Cláudio. A Regra do Jogo, São Paulo, Companhia das Letras, que relata o caso.

13 Muitas vezes, emissoras de rádio e televisão produzem informes sobre saúde pública com equívocos. Sem falar nos misticismos, charlatanismos, exoterismos. Nestes casos, a regulação estatal, mais do que apenas sugestiva, seria imperiosa.

14 Ver, por exemplo, o conflito jurídico em que se envolveu o jornal Notícias Populares, de São Paulo, ameaçado de circular em envelope lacrado por pressão dos organismos de defesa da criança e do adolescente.

15 Forçoso lembrar o episódio da retomada da luta pelos direitos civis negros americanos detonada pela divulgação de um vídeo onde um negro é espancado por policiais brancos.

16 Embora a lei atual os indenize, fato que proporcionaria uma boa discussão, a qual, no entanto, não cabe no âmbito deste trabalho, assim como outras características do HGPE brasileiro. 
170 raciocínio, como é evidente, vale para qualquer outra circunstância de transmissão em rede nacional, como aquelas às quais o presidente da República no Brasil tem o direito de convocar ou aquela diariamente veiculada por todas as rádios brasileiras.

\section{Referências}

ARENDT, Hannah. Da Revolução, 1983.

BARBALET, J. M.. A Cidadania. 1989

BOBBIO, Norberto. A Era dos Direitos. Rio de Janeiro: Campus, 1992.

Polis, 1990.

. As ideologias e o poder em crise. São Paulo:

O futuro da democracia: uma defesa das regras do jogo. Rio de Janeiro: Paz e terra, 1986.

Geral da Políica, 1987.

Estado, Governo, Sociedade ara Uma Teoria

CERRONI, Umberto. La ricomposizione Del moderno. Um nuovo racionalismo. In: Rinascita, n7; Nuova serie, anno II, 24 fev 1991.

HABERMAS, Jürgen. Mudança estrutural da Esfera Pública. Rio de Janeiro: Tempo brasileiro, 1984.

HIRSCHAMAN, Albert O. A Retórica da Intransigência. São Paulo: Companhia das Letras, 1992.

KORNHAUSER, William. The politics of Mass Society, 1991.

LAFER, Celso. A Reconstrução dos direitos humanos: um diálogo com o pensamento de Hannah Arendt. São Paulo: Companhia das Letras, 1988.

MACPHERSON, C. B. - Ascensão e Queda da Justiça Econômica, 1991.

POLANYI, Karl - A grande transformação, Rio de Janeiro, Editora Campus, 1980.

VECA, Salvatore. Cittadinanza: Riflessioni Filosofiche Sullidea Di Emancipazione. 1990. 